PART A: ARTICLES

\title{
SOCIAL JUSTICE: THE LINK BETWEEN TRADE LIBERALISATION AND SUB-SAHARAN AFRICA'S POTENTIAL TO ACHIEVE THE UNITED NATIONS MILLENNIUM DEVELOPMENT GOALS BY 2015
}

\author{
Ben Chigara*
}

The state is like the human body. Not all of its functions are dignified. Anatole France (1893)

\begin{abstract}
The possible impact of the unintended worst possible effects of the current multilateral WTO sponsored trade liberalisation project on Sub-Saharan Africa's potential to realise the Millennium Development Goals (MDGs) by the target date of 2015 is examined. The article shows that the WTO's current approach to trade liberalisation is nurturing and strengthening economic inequalities between and within economic regions of the world and also between and within States themselves without taking any steps to mitigate this difficulty. The article recommends the integration of ILO and WTO dynamics to ensure human development oriented wealth maximisation under the WTO trade liberalisation regime. In this sense the ILO would become the broker and insurer of equality in the dignity of labour between Sub-Saharan African workers and other workers of the world, increasing thereby the chances for Sub-Saharan African States to achieve the MDGs by the target date of 2015.
\end{abstract}

Research Professor of International Laws and Director of Enterprise and International Affairs, Brunel Law School, Brunel University, Uxbridge, United Kingdom. The author is grateful to Constance Chigara, Barnabas Chigara, Ben Chigara Jr, and Mainini Bridget Taremba for their encouragement. 


\section{INTRODUCTION}

International trade and social justice are interdependent, because they are both integral and critical to the raison d'être of why and how people everywhere engage in and conduct trade. ${ }^{1}$ The Peace Treaty of Versailles (1919) recognised this by providing for the creation of the International Labour Organisation (ILO) for the purpose of opposing conditions of social injustice that were linked to the industrial revolution. Then like now, the unbridled pursuit of economic growth had resulted in conditions of '.. such injustice, hardship, and privation to large numbers of people as to produce unrest so great that the peace and harmony of the world were imperilled'. ${ }^{2}$

However, the coupling of trade liberalisation issues with concerns of social justice has recently been criticised as an ambitious exercise in futility because of the two ideas' apparent exclusivity. The World Trade Organization (WTO)'s primary concern is to maximise gross international wealth creation ${ }^{3}$ through trade liberalisation. ${ }^{4}$ Non-discrimination of products and services from member States parties is the basic premise on which the system has been established. This is ensured by the requirement of two of its foremost principles, namely, the Most Favoured Nation (MFN) and the Nationality Treatment (NT) principles. ${ }^{5}$

1 The contrary view is that trade issues are distinct and separate from non-trade issues. See Alvarez, José E. et al., 'Symposium: The Boundaries of the WTO', American Journal of International Law, Vol. 96, No. 1, 2002 pp. 1-4, for a thorough discussion on the exclusivity of trade issues and the question whether alleged linkages of trade issues with other matters are valid or not. Discussing the undeniable link between trade and social justice see also Dommen, Caroline, 'Raising Human Rights Concerns in the World Trade Organization: Actors, Processes and Possible Strategies', Human Rights Quarterly, Vol. 24, No. 1, 2002, pp. 1-50. Discussing the regulation of bio-safety and international trade see also Qureshi, Asif H., 'The Cartagena Protocol on Bio-safety and the WTO Co-Existence or Incoherence?', International and Comparative Law Quarterly Review, Vol. 49, No. 3, 2000, pp. 835-855.

2 See appendix to the ILO Constitution (1919) available at ILO website, www.ilo.org/global/About_ the_ILO/Origins_and_history/Constitution/lang-en/index.htm\#annex (visited 20 January 2008). See also Chigara, Ben, 'Latecomers to the ILO and the Authorship and Ownership of the International Labour Code', Human Rights Quarterly, Vol. 29, No. 3, 2007, pp. 706-726.

3 Discussing the optimal mandate of the WTO and arguing for this function to be separated from non-market access issues, see also Bagwell, Kyle, Mavroidi, Petros C. and Staiger, Robert W. 'It's A Question of Market Access', American Journal of International Law, Vol. 96, No. 1, 2002, pp. 56-76.

4 Arguing that the WTO sponsored trade liberalisation project is nothing less than a convenient term to indicate US hegemony, see also Alston, Philip, 'The Myopia of the Handmaidens: International Lawyers and Globalization', European Journal of International Law, Vol. 8, No. 3, 1997, pp. 435-448, at p. 435 .

5 See Final Act Embodying the Results of the Uruguay Round of Multilateral Trade Negotiations Article 1, 15 April 1994, 33 International Legal Materials 1125, 1994. This requirement applies also to trade in services covered by the General Agreement on Trade in Services (GATS) Article 2, 15 April 1994, Marrakesh Agreement Establishing the World Trade Organization, Annex 1B, Legal Instruments - Results of the Uruguay Round, 33 International Legal Materials 1125, 1994, available at: www.wto.org/English/docs_e/legal_e/04-wto.pdf (last accessed 20 January 2008). 
But the WTO objective and modus operandi are significant for other stakeholders in international organisation, including the ILO that is concerned with the social impact of WTO policies on individuals everywhere because of its mandate to ensure universal social justice. Therefore, the UN as custodian of universal peace and security must account for the possibility, however remote, that WTO outcomes may adversely impact its grand strategies for peace building and peace making and also its aspiration to privilege, above all else, both the human rights and the human development agenda summed up in the Millennium Development Goals (MDGs) project. In contrast, the WTO agenda privileges first and foremost, the development of market efficiency everywhere. The push and pull factors that underpin ILO, UN, WTO, and other international organisations' activities necessarily pit themselves along one another's objectives in a complimentary way. Oftentimes they pit them one against the other. The tension created by their interaction is indicative of the absence of a formal hierarchy among international organisations. The consequent relational tensions can pour-over and threaten or actually impede the activities of one or other international organisation.

Neither GATT (the predecessor to WTO) nor the WTO has had a formal agreement with the UN. Formally, the extent of their relationship has been limited to an exchange of letters between the heads of these two bodies. In 1952, Eric Wyndham White (the first Executive Secretary of GATT) and Trygve Lie (the UN Secretary-General) exchanged letters that acknowledged the 'close de facto working arrangements which exist between the United Nations Secretariat and the Secretariat of the Interim Commission (GATT)'. ${ }^{6}$ Upon the creation of the WTO on 1 January 1995, a further exchange of letters occurred between the WTO Director-General (Renato Ruggiero)

See also Agreement on Trade-Related Aspects of Intellectual Property Rights (TRIPS) Article 4, 15 April 1994, Marrakesh Agreement Establishing the World Trade Organization, Annex 1C, Legal Instruments - Results of the Uruguay Round, 33 International Legal Materials. Examining the potential and actual effect on competition policy of member States parties of the WTO, see also Boughzala, Mongi, 'Impact On Workers of Reduced Trade Barriers: The Case of Tunisia and Morocco', International Labour Review, Vol. 136, No. 3, 1997, pp. 379-399, at p. 379. See also Lee, Eddy, 'Globalization and Labour Standards: A Review of Issues', International Labour Review, Vol. 136, No. 2, 1997, pp. 173-189, at p. 173; Gunter, Bernhard G. and Van der Hoeven, Rolph, 'The Social Dimension of Globalization: A Review of the Literature', International Labour Review, Vol. 143, No. 1-2, 2004, pp. 7-43, at p. 7; Servais, Jean-Michel, 'Globalization and Decent Work Policy: Reflections Upon a New Legal Approach', International Labour Review, Vol. 143, No. 1-2, 2004, pp. 185-207, at p. 185; and Milberg, William, 'The Changing Structure of Trade Linked to Global Production Systems: What Are the Policy Implications', International Labour Review, Vol. 143, No. $1-2,2004$, pp. 45-90, at p. 45.

6 Letter from E. Wyndham White, First Executive Secretary, General Agreement on Tariffs and Trade, to Trygve Lie, UN Secretary-General, 11 August 1952, in: UN Economic and Social Council (ECOSOC), 57 $7^{\text {th }}$ Session, Review of the Agreements Between the United Nations and the Specialized Agencies and the International Atomic Energy Agency, Exchange of Letters Between the Executive Secretary of the General Agreement on Tariffs and Trade and the Secretary-General, Letter dated 11 August 1952, UN Doc. E/5476/Add.12/Annex I, 24 May 1974, available at: www.unsystemceb.org/ reference/system/agreements/wto_gatt_e_5476_add12_1974 (last accessed 27 January 2008). 
and the UN Secretary-General (Boutros Boutros-Ghali) in October 1995, emphasising the cooperative nature of their relationship. This is noted also in the UN's General Assembly Resolution 322 of 12 December 1995.

Therefore, it would be helpful to commence this discussion with a brief characterisation of the issues in order to establish a framework for analysing the question of Sub-Saharan African States' potential to achieve MDGs by the target date of 2015 under the current multilateral trading system.

\section{TRADE LIBERALISATION AND SUB-SAHARAN AFRICA: FRIENDS OR FOES?}

\subsection{OVERVIEW OF SUB-SAHARAN AFRICA}

By any standard, Sub-Saharan Africa is the weakest region in the world in terms of economic and human development. It has just over ten percent of the world's population. However, it is home to 34 of the world's 49 least developed countries, and home to 64 percent of the world's HIV positive population. ${ }^{7}$ It continues to lose to Western States its own home talent of high and medium skilled professionals even though it is unable to attract foreign professionals of similar calibre. The United Kingdom (UK) Public Service Union UNISON writes that 'health care workers make up an increasing proportion of migrant workers in the UK, the majority of whom are from Sub-Saharan Africa.' ${ }^{8}$

Current patterns of skilled immigration to the UK are often ascribed to the emergence of global labour markets and the continuation of specific migration linkages that reflect not only the UK's historical position on international migration systems, but also its new distinctive position and functions in the global economy. ${ }^{9}$ The sum of the push and pull factors ${ }^{10}$ in the current skilled labour migration dynamic can only weaken Sub-Saharan Africa's ability to pursue its development goals more effectively.

7 Sub-Saharan Africa: UNFPA Worldwide, www.unfpa.org/africa/ (last accessed 28 January 2008). See also Centre for HIV Information website, University of California, available at: http://hivinsite. ucsf.edu/global?page $=$ cr09-00-00 (last accessed 27 January 2008).

8 UNISON, International Labour Migration - A UNISON Discussion Paper, 2002, available at: www.unison.org.uk/file/a2444.pdf.pdf (last accessed 27 January 2008). See also Bhorat, Haroon, Meyer, Jean-Batiste and Mlatsheni, Cecil, 'Skilled Labour Migration from Developing Countries: Study on South and Southern Africa' 2002, available at: www.ilo.org/public/english/protection/ migrant/download/imp/imp52e.pdf (last accessed 27 January 2008); and Davis, Catherine R. and Nichols, Barbara L., 'Foreign-Educated Nurses and the Changing U.S. Nursing Workforce', Nursing Administration Quarterly, Vol. 26, No. 2, 2002, pp. 43-51, at p. 43.

9 See also Findlay, Allan, 'From Brain Exchange to Brain Gain: Policy Implications for the UK of Recent Trends in Skilled Migration from Developing Countries', 2001, available at: www.ilo.org/ public/english/protection/migrant/download/imp/imp43.pdf (last accessed 27 January 2008).

10 Examining the dynamics that underpin skilled labour migration, see Bhorat, Meyer and Mlatsheni, loc.cit. (note 8 ). 
Currently, the region does not appear capable of either attracting or retaining foreign skilled professionals at the same levels that it is losing its own professionals to the Western world.

The United Nations Population Fund's (UNFPA) assessment of Sub-Saharan Africa's potential to meet its development goals is bleak. UNFPA has characterised the challenges facing Sub-Saharan Africa as 'the most daunting facing any region in the world. These objectives include reaching the eight Millennium Development Goals (MDGs) for 2015 and the closely related goals for 2015 set at the ICPD in 1994 and the ICPD+5 follow up in 1999'. ${ }^{11}$ UNFPA lists the devastating AIDS pandemic, massive human displacements caused in part by frequent occurrence of natural disasters, violent conflicts and debilitating political strife as the main impediments in the effort to achieving the goals of countering poverty, empowering women, reducing child mortality and improving maternal health in the region. ${ }^{12}$

These observations inspire little confidence that Sub-Saharan Africa will have achieved its economic and human development goals by 2015. According to the UNFPA, this region will continue to require the highest per capita levels of technical and financial support of any region, if it is to make significant progress towards achieving the MDGs by 2015. This situation raises the question of the justiciability of the multilateral WTO trading system whose policies and operational dynamic disregard Sub-Saharan African States' unique circumstances by subjecting them equally to the rigors of the trade liberalisation project.

The result is that Sub-Saharan Africa's economies have to compete on an even keel with those of developed States. Their numerical strength - one quarter of the total membership of the WTO - is neutralised by the WTO's modus operandi. ${ }^{13}$ This appears to be a contradiction of sorts, because research suggests that developed economies continually strategise to ensure that developing economies just barely cope, but cannot compete with them. ${ }^{14}$

\subsection{WTO THEORETICAL FRAMEWORK COMPATIBILITY WITH SUB-SAHARAN AFRICA}

Howse's ${ }^{15}$ lucid examination of the foundations and underpinnings of the modern international trading system shows that the WTO is premised on the theory of classic

Sub-Saharan Africa: UNFPA Worldwide, loc.cit. (note 7).

Idem.

Numbering 149 States as of 11 December 2005. See generally WTO, 'Understanding the WTO members', www.wto.org/english/thewto_e/whatis_e/tif_e/org6_e.htm (last accessed 27 January 2008).

14 Chigara, Ben, 'Trade Liberalization: Saviour or Scourge of SADC Economies?', University of Miami International and Comparative Law Review, Vol. 10, Special Issue, 2001-2002, pp. 7-21, at p. 21.

15 See Howse, Robert, 'From Politics to Technocracy - and Back Again: The Fate of the Multilateral Trading Regime', American Journal of International Law, Vol. 96, No. 1, 2002, pp. 94-117, at p. 94. 
insights of absolute and comparative advantage developed by Adam Smith and David Ricardo. ${ }^{16}$ Under this paradigm the primary function of the WTO is to facilitate interState trade in order to maximise gross international wealth.

But comparative advantage theory's biggest weakness is that it focuses only on wealth creation without providing for the corresponding issue of the distribution of the consequent wealth. Lubker's ${ }^{17}$ survey of people's perceptions of inequality in 30 countries shows that the majority of people (opinio communitatis) prefer to rethink the current drivers of global governance as a means of arresting the growth and extent of economic inequality both within and between States and economic regions of the world - what the ILO World Commission on the Social Dimension of Globalisation ${ }^{18}$ has called an unfair and uninclusive globalisation that alienates the majority from current opportunities and benefits of the international trading system.

This is because the principle of absolute and comparative advantage on which the modern international trading system is premised, neglects the question of the redistribution of the wealth that it might create. Rather its focus is squarely on the creative function and ability of the international trading system to maximise international wealth creation, supported of course by the judicial supervisory function of the WTO dispute settlement body. ${ }^{19}$ Instead, it concerns itself with the efficacy and interdependency of different States' trade and other economic policies. By eliminating inefficient practices in the global trading system, it hopes to discipline States to impose external trade costs on other States by virtue of their own domestic policies. A paramount goal of the multilateral WTO system is the minimisation of protectionist summum malum. ${ }^{20}$ However, this makes the WTO pretentious in that it assumes without any justification whatsoever, ${ }^{21}$ that the benefits of trade liberalisation

See also Jackson, John H., 'Afterword: The Linkage Problem - Comments on Five Texts', American Journal of International Law, Vol. 96, No. 1, 2002, pp. 118-125, at p. 118.

16 Holding that a policy of liberalising on imports, developed by the classical political economists Adam Smith and David Ricardo, maximises the wealth of the liberaliser, see also Howse, loc.cit. (note 15). But challenging the validity of this view when the structural changes in the composition of international trade are taken into account, see Milberg, loc.cit. (note 5).

17 Lubker, Malte, 'Globalization and Perceptions of Social Inequality', International Labour Review, Vol. 143, No. 1-2, 2004, pp. 91-128, at p. 91.

18 World Commission on the Social Dimension of Globalisation, 'A Fair Globalization: Creating Opportunities for All', available at: www.ilo.org/public/english/wcsdg/docs/report.pdf (last accessed 23 January 2008).

19 See generally Iwasawa, Yuji, 'WTO Dispute Settlement as Judicial Supervision', Journal of International Economic Law, Vol. 5, No. 2, 2002, pp. 287-305, at p. 287. See also Understanding on Rules and Procedures Governing the Settlement Dispute Article 3, 15 April 1994, Marrakesh Agreement Establishing the World Trade Organization, Annex 2, Legal Instruments - Results of the Uruguay Round, 33 International Legal Materials 1125.

20 Howse, loc.cit. (note 15); and see Jackson, loc.cit. (note 15), at p. 122 (observing additional goals added onto the WTO in the last decade or two, namely the alleviation of poverty and the management of the risk of global financial and economic crises).

21 Examining whether and to what extent trade liberalisation as a policy requires responsibility of those that benefit the most to compensate those that lose the most under a trade adjustment 
will perhaps through some as yet unknown, inherent and magical characteristic or, that by some wondrous external inspiration, result in an equitable and satisfactory distribution of its harvests between States, and leaving them all better off. ${ }^{22}$ This is illusory for several reasons.

Firstly, even if we assumed that the gross international wealth resulting from States' adherence to WTO policies somehow satisfactorily divided itself between States according to their needs, we would still be short of discovering first, what the needs of each State were; secondly, how those needs were determined to ensure parity among States; and thirdly, how those needs would be ranked, classified, aggregated, and weighted proportionately to determine their share of the consequent gross international wealth to be shared out among member States parties. We would still be short of discovering by what authority anyone made all the determinations referred to above.

Secondly, even if we assumed that the matrix for the determination of each State's share of the resultant international wealth also indicated a corresponding measure of each State's actual effort to the wealth creation endeavour, the problem would still subsist about the actual value to be given to each of the essentials such as labour, ideas, capital, and so on. The classification of first, the weight and value of each State's contribution to the international wealth creation effort, and secondly, each State's corresponding entitlement $v i s-\grave{a}$-vis the resultant international wealth would be fraught with all sorts of statistical, practical and systematic problems. It would prompt labour rich States to accuse capital rich States of Apartheid.

The determination of the corresponding proportion of each State's contribution to the available gross international wealth would be problematic. For example, the cost of industrial labour has caused all sorts of social and economic problems in both hemispheres since the launch of the policy of trade liberalisation, as investors chase up cheap labour and low taxes in order to maximise their own profit margins.

Gunter and Van der Hoeven write that investors base their decisions on the location of production on 'the most competitive combination of labour, technology, structural advantages and business environment which includes, inter alia, low taxes on profit and political stability'. ${ }^{23}$ This could explain the race in the 1990s among high and middle-income States towards the lowest possible denominator regarding the question of the value of labour in wages. Empirical research shows a marked transfer during this period of manufacturing production from the industrialised countries to the developing countries. ${ }^{24}$ How does one determine under these circumstances what the needs of each State should be, or indeed what the proportionate value of each

assistance programme, see also Kapstein, Ethan, 'Trade Liberalization and the Politics of Trade Adjustment Assistance', International Labour Review, Vol. 137, No. 4, 1998, pp. 501-516, at p. 501.

22 The third of Dunkley's three myths about the free trade project. Dunkley, G., Free Trade: Myth, Reality and Alternatives, Zed Publishers, London, 2004, p. 5.

23 Gunter and Van der Hoeven, loc.cit. (note 5), at p. 17.

24 Idem. 
State's contribution to the gross global wealth may be at any point in the international economic cycle?

One way to resolve this difficulty would be for the WTO to establish an agency ${ }^{25}$ that approved the social benefit of market products worldwide. Such an agency would have the power to impose a prohibition in trade against all products that did not have the 'workers earned a decent wage' seal of approval. This requirement would refocus the emphasis from the necessary ${ }^{26}$ search for an elusive distributive system for sharing out the gross international wealth that resulted from States' adherence to WTO policies, to an emphasis on decent treatment of all workers of the world through decent pricing of their labour. This would reinforce also current and ongoing ILO efforts to ensure everywhere that decent work was rewarded with decent remuneration. ${ }^{27}$ Nonetheless, this problem reveals the pretentious nature of the WTO's selling point, that is, that all States that embrace its regime, will be better off in spite of the apparent absence of a distributive mechanism to allocate the consequent international wealth.

Moreover, there is neither practical nor empirical evidence in support of the proposition that every State that participates in the multilateral trading system, will end up better off. The reality is that States are faring very differently, with the economically strong States getting stronger and the weak ones getting weaker. States' national wealth is increasingly confined within the hands of a very small number of individuals - what one might perhaps call 'the slavery of trade liberalisation'. ${ }^{28}$ Evidence of this is commonplace.

The UNDP annual Human Development Report (2005) ${ }^{29}$ shows that:

- The fight against poverty and the realisation of the MDGs have made only limited progress. Current trends indicate that, unless intervention is made to arrest the situation, 827 million people will be living in extreme poverty by 2015 .

- Fifty countries have actually lost ground with regards to at least one goal - this relates especially to southern Africa, which has been decimated by the HIV/AIDS pandemic. Twelve of the 18 countries whose HDI is lower than it was in 1990, are African.

25 The ILO has a long history and experience of doing this. See generally Richthoven, Wolfgang, Labour Inspection: A Guide to the Profession, International Labour Office, Geneva, 2002.

26 Gunter and Van der Hoeven, loc.cit. (note 5), at p. 20.

27 International Labour Organisation, 'Decent Work and the Informal Economy', Report VI, 90 ${ }^{\text {th }}$ Session, 20 June 2002.

28 See Khan-Freund, Otto, 'Notes of Cases - Servants and Independent Contractors', Modern Law Review, Vol. 14, No. 4, 1951, pp. 485-511, at pp. 485-504.

29 Martens, Jens, Global Policy Forum, Dialogue on Globalization Briefing Papers, 'A Compendium of Inequality: The Human Development Report 2005 - FES Briefing Paper October 2005', available at: www.globalpolicy.org/eu/en/publ/fespaper4hdr2005.pdf (last accessed 27 January 2008). See also United Nations Development Programme (UNDP), Annual Report 2005, 'A Time for Bold Ambition: Together We Can Cut Poverty in Half', available at: www.undp.org/annualreports/2005/english/ IAR05-English.pdf (last accessed 27 January 2008). 
- Fifty individuals in the world have a combined income greater than that of the poorest 416 million.

- There are two and a half million persons living on less than two dollars a day.

- Forty percent of the world's population receive only five percent of global income.

- The richest ten percent of the world's population receive 54 percent of the global income.

However, in spite of this, the WTO still promises overall economic progress for all member States parties of the organisation that adhere to its regime. ${ }^{30}$ This underlines the organisation's preoccupation with, and assimilation of classical insights about the benefits of trade liberalisation. It is not surprising that the first dozen years' practice of the WTO system has resulted in mixed and alarmingly divergent outcomes for different member States parties, for different economic regions, and for different categories of States contrary to the promise of positive outcomes for all.

Among other concerns, this begs the question of whether the classical theory of comparative advantage is appropriate to international trade law's post-war goal of enabling States to manage their domestic economies in a manner that is 'consistent with political and social stability and justice, without the risk of setting off a protectionist race to the bottom. ${ }^{31}$ This is the challenge that faces the innovators of the WTO multilateral trading system.

This article focuses on the possible impact on Sub-Saharan Africa of the current WTO sponsored policy of trade liberalisation in relation to the question of whether, and to what extent the UN will have achieved the MDGs by the target date of 2015 in that region. It shows that the current WTO sponsored trade liberalisation project might have nurtured, extended and strengthened the economic inequalities between and within economic regions of the world, and also between and within States themselves.

Murphy writes that Americans are getting poorer except for the top 20 percent of the population, as more and more income shifts to the very top, and the American Dream becomes less and less attainable for more than 80 percent of the population.

The differences between the top fifth - the richest - and the bottom fifth - the poorest is almost equal to what it was during the Great Depression, with no New Deal in sight. (...) This discrepancy was made painfully apparent during the Hurricane Katrina disaster when the poorest of New Orleans' inhabitants - the bottom fifth, suffered the lack of nearly all life-sustaining resources. ${ }^{32}$

The UNDP reports that differences are acutely extreme within Namibia, Zimbabwe, South Africa, Chile, and Brazil.

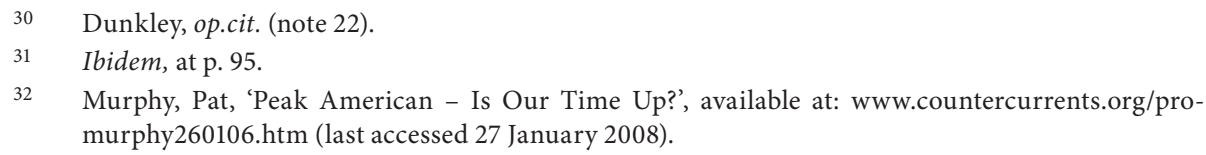




\section{EMERGENT WTO OUTCOMES}

\subsection{GINI-COEFFICIENT INDICATORS}

Measurement of the inequality in the income distribution - known as the Ginicoefficient - not only confirms economic inequality within and between States, but signals a threat to international peace and security from poverty. ${ }^{33}$ Available data shows that 80 percent of the world's population is spread across countries where the Gini-coefficients are unacceptable.

The Gini-coefficient is a number between zero and one that measures the degree of inequality in the distribution of income in a given society. The coefficient would register zero $(0.0=$ minimum inequality $)$ for a society in which each member received exactly the same income and it would register a coefficient of one $(1.0=$ maximum inequality) if one member got all the income and the rest got nothing. ${ }^{34}$

A Gini-coefficient of 0.3 or less is generally accepted as normal. However, anything higher is considered unstable. A value of 0.6 or higher is predictive of social unrest. The UNDP Annual Report (2005) observes that in 200345 million Americans lacked basic health insurance. This figure was made up of 34 percent Hispanic Americans, 21 percent Afro-Americans, and only 13 percent white Americans. This social inequality in the affordability of health service in the USA resulted in a disproportionate experience of infant mortality rates which were twice as much among Afro-Americans as for white Americans.

One consequence of such economic inequalities, wherever they occur, is the facilitation of the development of a social dynamic that ensures, sustains, and even fosters the cycle of poverty instead of challenging, limiting and uprooting it. Even worse, these economic inequalities can breed a human desperation and ruthlessness that creates opportunities for such practices as illegal inter-State and inter-regional economic immigration. This is often accompanied with a breakdown of family ties for those involved and the facilitation of such anti-human rights practices, such as human trafficking and economic enslavement of illegal economic migrants in prostitution and other illegal and/or hazardous occupations with no regard to national health and safety standards. The ILO writes that

[o]f the eighty to ninety-seven million migrant workers and their dependents now in countries other than their own, it is estimated that perhaps no less than fifteen percent are working on an irregular basis. (...) In addition to fostering irregularity, this climate has contributed to the opening up of a lucrative market for the smuggling and trafficking of

33 The Secretary-General of the UN is on record for arguing that a world mired in poverty cannot be a world at peace. UNDP, '2015: Ten Years to Change the World', available at: www.unpd.org/ annualreports/2005/english/IAR05-English-TenYears.pdf (last accessed 27 January 2008).

34 Gini-coefficients, available at: http://berclo.net/page01/01en-gini-coef.htm (last accessed 27 January 2008). 
migrant workers. Women and children are especially victimized; many are trafficked into conditions of slave labour and/or forced prostitution. The human suffering, maltreatment and exploitation that ensue as a result require little explanation and have been the focus of much media, governmental and NGO attention..$^{35}$

Such economic inequalities and anti-human rights practices justify the mobilisation of international action to ensure the delivery by States on human rights standards that they have long promised to recognise, promote and protect for all individuals on their territories. The UN MDGs seek to mobilise international action for that purpose.

\subsection{THE UN MILLENNIUM DEVELOPMENT GOALS AND WTO OUTCOMES}

The MDGs are not mere aspirations, but a compact between rich and poor States to achieve a balance in the new millennium between the pursuit of economic growth ${ }^{36}$ on the one hand, and human development on the other. The purpose is to better facilitate the fight against poverty and preventable and curable disease, provisions of education and decent work for many and not the few worldwide. This compact is set in eight measurable time bound goals agreed on 8 September 2000 by 189 States attending the Millennium Summit at the UN Headquarters in New York - the Millennium Declaration. ${ }^{37}$ The Declaration lists concrete goals, with outcomes that can be monitored and measured through the way to the target date of 2015. Therefore, the MDGs declare and herald a human development agenda for the new millennium. ${ }^{38}$

The UNDP ${ }^{39}$ has characterised the UNMDGs as:

- A new framework for development that demands results and increases accountability.

- A time bound, measurable development manifesto for ordinary individuals around the world.

- An agenda for elevating poverty to the top of the global agenda.

$35 \quad$ International Labour Migration - About MIGRANT, Migrations Concerns: Irregular Migration and Exploitation of Labour, available at: www.ilo.org/public/english/protection/migrant/about/ index.htm (last accessed 27 January 2008).

36 Research shows that the first, second, and third UN development decades, the 1960s, the 1970s, and the 1980s respectively were concerned with economic transformation and growth. Industrialisation was privileged above all else. See Fukuda-Parr, Sakiko, 'Millennium Development Goals: Why They Matter', Global Governance, Vol. 10, No. 4, 2004, pp. 359-402, at p. 395.

37 United Nations Millennium Declaration, GA Res. 55/2, UN Doc. A/RES/55/2, 8 September 2000.

38 Fukuda-Parr, loc.cit. (note 36).

39 See UNDP website at: www.undp.org/mdg/basics.shtml (last accessed 27 January 2008). See also Chigara, loc.cit. (note 2). 
- A means for better managing globalisation ${ }^{40}$ on behalf of poor people.

An immediate accomplishment of the Millennium Declaration's eight goals which range from halving extreme poverty, to halting the spread of HIV/AIDS by 2015 has been the refocus of developmental targets and goals of governments, aid agencies and civil society organisations everywhere. Nonetheless, research shows that if they are to achieve the UNMDGs by 2015, two groups of countries require a quick and radical change.

One is the group of 59 'top priority and high priority' countries that are characterised by low human development and poor performance in relation to the MDGs. ${ }^{41}$ The other comprises countries that are making progress towards the realisation of the goals but with deep pockets of poor people being left behind. Sub-Saharan Africa alone has 25 top priority countries and 13 high priority countries. This makes SubSaharan Africa the central object of poverty and hunger and underdevelopment among the regions of the world.

In a sense, the MDGs are the boldest declaration since the Universal Declaration of Human Rights $(1948)^{42}$ that the pursuit of economic growth - with all the benefits it brings, ${ }^{43}$ should not be privileged above human development. In this sense, the MDGs evidence is a desperate effort by the UN to minimise its failure ${ }^{44}$ in the past to promote the rights that are specifically being championed under the MDG programme. ${ }^{45}$

In spite of an inspiring and committed legislative campaign to ensure the security and welfare of individuals through the development of international human rights covenants and treaties, for nearly 60 years, success stories are few and far between and overcrowded with alarming failures. Poverty still reins unrestricted in countries

40 Globalisation is a bi-product of irreversible creative synergies that have facilitated freer trade, technological advancement, deeper cross-border production structures and systems, increased capital and human mobility, and greater information flows and communication. See Gunter, Bernhard G. et al., 'Special Issue: More Equitable Globalization', International Labour Review, Vol. 143, No. 1-2, 2004, pp. 7-43. See also Ghose, Ajit K., Jobs and Incomes in a Globalising World, International Labour Organisation, Geneva, 2003.

41 See generally UNDP, Annual Report 2003, 'A World of Development Experience', June 2003), available at: www.undp.org/annualreports/2003/english/IAR03completeE.pdf (last accessed 27 January 2008).

42 See Fukuda-Parr, loc.cit. (note 36) (discussing the significance of the UN MDGs).

43 Economic growth is critical to human welfare. Nonetheless, it depends on human beings for its creation. Therefore, in a sequential sense, it must serve humans for its own good. Ultimately, it depends on humans.

44 In particular, the issue of slavery has not been acknowledged to the same extent that Nazism has been in spite of the closeness of the ideologies. Colonialism was legal under international law and no redress has ever been paid by colonial masters for the dehumanising practice. See Chigara, Ben, 'Short-Circuiting International Law', Oregon Review of International Law, Vol. 8, No. 2, 2006, pp. 191-229, at p. 191.

45 Analysing both the logic and magnificence of the vision that began the human rights legislative process see Legomsky, Stephen H., 'The United Nations and the Protection of Human Rights', Washington University Journal of Law and Policy, Vol. 5, No. 1, 2001, pp. 7-17, at p. 7. 
that make up 80 percent of the world population; preventable and curable diseases alarmingly continue to maim and kill women and children especially in the developing world. ${ }^{46}$

Thus, the MDGs could be defined as an attempt to re-launch the human rights commitments that States had previously made but failed to realise for people everywhere. The MDGs established standards for the progressive realisation of previously neglected economic and social rights by integrating political factors such as civil rights and democratic representation with social factors such as education and health, and economic factors such as growth and employment.

Contrary to the WTO value system, but just like the ILO, the MDGs regard people as the key agents of change and not as mere beneficiaries of progress. ${ }^{47} \mathrm{UNDP}^{48}$ has summarised the potential benefits of achieving the MDGs as follows:

- Removing 500 million people from extreme poverty

- Removing 300 million people from extreme hunger

- Ensuring safe drinking water for 350 million more people

- Ensuring that 30 million more children will live beyond their fifth birthdays

- Ensuring that two million more women will survive childbirth

Instead, the unintended, worst possible effects of the current WTO sponsored trade liberalisation project stand in the way of the achievement of the MDGs by the target date of 2015, especially in Sub-Saharan Africa. While it is correct to say that there cannot be progress towards achievement of the MDGs by the target date of 2015 in the absence of economic wealth; it is even more correct to say: (i) that the conditions under which that wealth is created are themselves a test of whether and to what extent progress has occurred towards achievement of the MDGs; and (ii) that allocation and distribution within and between States of the social power that determines the distribution of the wealth resulting from States' adherence to the WTO policy of trade liberalisation is even more important because:

- A major function of the MDGs is to undercut poverty, privation and avoidable human suffering. Therefore, economic practices that extend social inequalities to the extent of breeding such crimes as human trafficking, enslavement, forced prostitution, and so on, are themselves as bad as the wealth that they create - black wealth.

- Progress towards the achievement of the MDGs should be made and funded only by 'clean' international wealth because of the moral significance that has been attached to the programme. This implies that workers that produce that wealth

\footnotetext{
46 See Martens, loc.cit. (note 29).

$47 \quad$ Fukuda-Parr, loc.cit. (note 36), at p. 396.

48 UNDP, loc.cit. (note 29), at p. 10.
} 
must be involved in decent work, and working under humane conditions that include payment of decent wages.

- Maximisation of gross international wealth is acceptable only if its procedures recognise workers as separate and not the same as or equal to other capital required in economic endeavour. It should be acceptable for application in the cause of the MDGs only if it recognises, respects and promotes the dignity inherent in its producers as human beings.

\subsection{COMBINING ILO AND WTO DYNAMICS TO ENSURE HUMAN DEVELOPMENT ORIENTED WEALTH MAXIMISATION}

As a consequence of the foregoing discussion, this article recommends first, institutional and policy interventions that target the minimisation in Sub-Saharan Africa, the unintended worst possible effects of the current WTO sponsored trade liberalisation project. In particular, the article recommends ILO supervision of the WTO enterprise in Sub-Saharan Africa in order to balance economic growth against human development. This could include ILO training and provision of direct guidance and assistance to government departments and officials of Sub-Saharan African States on such matters as negotiation, reception and management of foreign direct and indirect investment schemes, and ensuring that foreign investors observe all the minimum industrial relations standards that have been endorsed by the ILO Conference and Governing Body. In this sense, ILO would become the broker and ensurer of equal dignity of labour between Sub-Saharan African workers and workers everywhere else in the world.

This recommendation should be acceptable, because it is consistent with the ILO's originating purpose, which is to counter the economic and social injustices and inequalities that accompany social and economic change. ${ }^{49}$ Formally, the Treaty of Versailles (1919) provided in Article 387 for the creation of the International Labour Organisation for the purpose of attending terrible conditions of labour. ${ }^{50}$ Considerations of humanity and fear of unfair competition galvanised the commitment to secure a universal social policy for the global world of work.

ILO is immensely experienced at developing, monitoring and enforcing social justice standards across the world. ${ }^{51}$ Moreover, the link between WTO and ILO enterprises is a matter of fact. ${ }^{52}$ ILO is the custodian of workers rights in the United

49 Chigara, loc.cit. (note 2).

50 Idem.

51 Evaluating the standard-setting activity of the ILO and its procedures for monitoring their application, see also Wisskirchen, Alfred, 'The Standard-Setting and Monitoring Activity of the ILO: Legal Questions and Practical Experience', International Labour Review, Vol. 144, No. 3, 2005, pp. 253-289, at p. 253.

52 See Alvarez, José E., 'The WTO as Linkage Machine', American Journal of International Law, Vol. 96, No. 1, 2002, pp. 146-148, at p. 146. 
Nations system. ${ }^{53}$ Juan Somavia, the ILO Director General, writes that the primary goal of ILO today is to promote opportunities for women and men to obtain decent and productive work, in conditions of freedom, equity, security and human dignity. Decent work is summed up as that which:

sums up the aspirations of people in their working lives. It involves opportunities for work that is productive and delivers a fair income, security in the workplace and social protection for families, better prospects for personal development and social integration, freedom for people to express their concerns, organize and participate in the decisions that affect their lives and equality of opportunity and treatment for all women and men. [For this reason it] (...) should be at the heart of global, national and local strategies for economic and social progress. It is central to efforts to reduce poverty, and a means for achieving equitable, inclusive and sustainable development. The ILO works to promote decent work through its work on employment, social protection, standards and fundamental principles and rights at work and social dialogue. ${ }^{54}$

This mission realises that the world is burdened with tired, overworked and unemployed people. It targets workers everywhere, including the unregulated wage earners, the self-employed, domestic workers and 'unrecognised workers'. ${ }^{55}$

During the eight-year negotiations to establish WTO (1986-1994), controversy erupted in the 1980s over proposals to include a social clause in agreements negotiated during the Uruguay Round. ${ }^{56}$ Although the Final Act of the Uruguay Round signed at Marrakech, Morocco in April 1994 avoided explicit reference to a social clause, the ILO immediately established in June 1994 'The Working Party on the Social Dimensions of the Liberalization of International Trade'. ${ }^{57}$ These two developments served as a marker for the contentious issues that would attend the WTO sponsored trade liberalisation project. They served to underline an inevitable connection between trade liberalisation matters, and social justice issues. ${ }^{58}$

53 See Sen, Amartya, 'Work and Rights', International Labour Review, Vol. 139, No. 2, 2000, pp. 119-128.

54 Somavia, Juan, Director General, ILO, 'Decent Work - The Heart of Social Progress', available at: www.ilo.org/public/english/decent.htm (last accessed 27 January 2008). See also Paratian, Rafendra and Dasgupta, Sukti (eds), ILO Socio-Economic Security Programme: Confronting Economic Security in Africa, International Labour Office, Geneva, 2004.

55 Sen, loc.cit. (note 53), at pp. 119-128.

56 See Leary, Virginia A., 'The WTO and the Social Clause: Post-Singapore', European Journal of International Law, Vol. 8, No. 1, 1997, pp. 118-122, at p. 118. See also Torres, Raymond, Towards a socially sustainable world economy: An analysis of the social pillars of globalisation, International Labour Office, Geneva, 2001, p. 3.

57 See International Labour Organization, 'Governing Body - Minutes, 260 ${ }^{\text {th }}$ Session, June 1994.

58 On the links between the WTO enterprise and non trade issues, including corruption and bribery, health care, environmental concerns, culture, and so on, see Alvarez et al., loc.cit. (note 1). 


\subsection{A SOCIAL JUSTICE TEMPERED INTERNATIONAL TRADING REGIME}

For several reasons, the struggle for social justice in international trade is a worthwhile enterprise. Firstly, it is one way by which the prevalence of the worst unintended effects $^{59}$ of the current WTO sponsored international trade liberalisation project could be monitored, controlled and reduced to make trade liberalisation both efficient and balanced in order to avoid replacing one evil with another. ${ }^{60}$ Secondly, research is unclear about whether the current WTO sponsored trade liberalisation project is undermining previous achievements of ILO. ${ }^{61}$ Nonetheless, there is strong empirical evidence to support the view that:

- Conditions of work and employment appear to improve with economic growth and trade liberalisation. ${ }^{62}$

- The pursuit of decent work for all more often than not leads to both human development and economic growth. ${ }^{63}$

- Countries that are characterised by low labour standard do not necessarily have an inferior export nor do they attract more FDI. ${ }^{64}$

Thirdly, the UN has staked the conscience of the world on the achievement of the MDGs by the target date of 2015. For this reason, it is necessary to explore the possibility of reconciling the enterprises of the UN, ILO and WTO in relation to the MDGs.

This article argues for a counterbalancing of the enterprises of ILO and WTO enterprises in order to mobilise a significantly international effort towards achievement of the UN MDGs and to facilitate the security of the welfare of individuals everywhere. It insists that ILO should have a significant role to play in the effort to ensure the

59 An opposite outcome to that targeted by the sponsoring 'expected utility' principle. See Kovandzic, Tomislav V. et al., 'Unintended Consequences of Politically Popular Sentencing Policy: The Homicide Promoting Effects of “Three Strikes” in U.S. Cities (1980-1999)', Criminology and Public Policy, Vol. 1, No. 3, 2001-2002, pp. 399-424, at p. 399.

60 Quoting Emmanuel, Arghiri, Appropriate or Underdeveloped Technology, John Wiley and Sons, London, 1982; Bardhan writes that 'If capitalism is hell here exists a still more frightful hell: that of less developed capitalism'; Bardhan, Pranab, Social justice in the Global Economy, International Labour Organisation, Geneva, 2000, p. 19.

61 For example, Ghose, Ajit K., 'Trade Liberalization, Employment and Global Inequality', International Labour Review, Vol. 139, No. 3, 2000, pp. 281-305, at p. 281; Torres, op.cit. (note 56), at pp. 51-66; and Lübker, Malte, 'Globalization and Perceptions of Social Inequality', International Labour Review, Vol. 143, No. 1-2, 2004, pp. 91-128, at p. 91.

62 Flanagan, Robert J. and Gould IV, William B. (eds), International Labour Standards: Globalisation, Trade and Public Policy, Stanford University Press, Stanford, 2003, p. 4.

63 Idem.

64 Idem. 
limitation of the unintended worst effects of the current WTO sponsored trade liberalisation project because:

1) It is the oldest and most experienced agency of the $\mathrm{UN}^{65}$ with both logistical and operational capacity to tackle and manage the unintended worst forms of social injustice that may unwittingly accompany the WTO trade liberalisation dynamic.

2) It is specifically mandated to pursue social justice for people everywhere and inter-State trade is a matter of concern for ordinary individuals in every country on earth. ${ }^{66}$ There is little reason to celebrate the achievements of WTO policies and practice in Sub-Saharan Africa. ${ }^{67}$ In spite of the WTO promise of improved economic performance for all States, Sub-Saharan African States remain economically dependent on the gratuitous tolerance of more powerful economic trading blocs such as the EC and nation States such as the USA. ${ }^{68}$

3) The linkage between globalisation and human development is incontestable, because ultimately it is trade or the absence of it that drives ordinary peoples' livelihoods everywhere. Globalisation is about market competition and efficiency. Because more than 50 nations have become economically poorer, and therefore, worse-off since the WTO inspired trade liberalisation policy was launched - nearly all of them African - UNDP writes that the long term initiatives to halve hunger and poverty contained in the UN MDGs will fail, unless the global trading system is overhauled fundamentally. ${ }^{69}$ This article argues for that overhaul to be inspired and guided by the ILO's pursuit of social justice for people everywhere.

65 ILO was founded in 1919 and is the only surviving major creation of the Treaty of Versailles, which brought the League of Nations into being. It became the first specialised agency of the UN in 1946. See ILO - About the ILO, available at: www.ilo.org/public/english/about/index.htm (last accessed 27 January 2008).

66 See ILO, Constitution, Preamble, 1919, available at: www.ilo.org/public/english/about/iloconst.htm (last accessed 27 January 2008) (hereinafter ILO Constitution).

67 See Chigara, loc.cit. (note 14), at pp. 7-21. See also African Growth and Opportunity Acceleration Act of 2004, H.R. 4103, 108th Cong., 2004 (enacted) (hereinafter AGOA Acceleration Act of 2004). See generally AOGA Background, available at: www.agoa.gov/agoa_legislation/agoa_legislation.html (last accessed 27 January 2008) (explaining that the African Growth and Opportunity Act (AGOA) was signed by President Bush on 18 May 2000 into law as Title 1 of The Trade and Development Act of 2000, and that the Act offers is intended to encourage African countries to continue their efforts to open their economies and to build free markets). See also The White House, 'President Bush Signs African Growth and Opportunity Act: Remarks by the President at Signing of the AGOA Acceleration Act of 2004', available at: www.whitehouse.gov/news/releases/2004/07/20040713-3. html (last accessed 27 January 2008) (hereinafter Remarks by the President at 2004 AOGA Signing).

68 See also AGOA Acceleration Act of 2004, supra note 67. See generally AGOA Background, supra note 67; and see also Remarks by the President at 2004 AOGA Signing, supra note 67.

69

Chigara, loc.cit. (note 2). 
First, this article tests the claims of the multilateral WTO trading system to make all member State parties better-off ${ }^{70}$ against the experience of Sub-Saharan African States. The findings point to sharp inconsistencies between WTO politics and promises on the one hand, and the experience of Sub-Saharan African States on the other. This disparity strengthens the tension between the increasingly people oriented welfare model of the UN and the capitalist oriented market model of the multilateral WTO trading system.

Secondly, the article examines claims of linkages between trade liberalisation and social justice. ${ }^{71}$ It makes the case for counterbalancing the enterprises of the multilateral WTO trading system and the ILO. Both organisations have separate distinct origins from the $\mathrm{UN}$, although the latter is the dominant vision caster of the international organisation. Although it predates the UN, ILO entered on 14 December $1946^{72}$ as a specialised agency agreement with the UN, making it part of the UN. However, WTO has no such agreement with the UN. It remains autonomous.

While WTO's main concern is the maximisation of gross international wealth, ILO is mainly concerned with securing international peace and security through the guarantee of social justice for individuals everywhere. Both ILO and WTO each have a critical potential to impact the achievement or failure of the UNMDGs by the target date of 2015.

\subsection{A TENSION BETWEEN UN AND WTO ENTERPRISES?73}

The question of distribution of the gross international wealth that is created by States' adherence to WTO policies is critical to any attempt to evaluate the UN's potential to achieve its MDGs in Sub-Saharan Africa by the target date of 2015. One reason for this appears to be that the WTO economic and trade paradigm deliberately side steps issues of ownership, disbursement and enjoyment of the gross international wealth that may result from States' application and adherence to its regime. Therefore, it is not surprising that WTO has not factored into its blueprint measures to mitigate against the worst possible unintended effects of its regime on States. This omission now appears to threaten the realisation of the UN MDGs in Sub-Saharan Africa by

$70 \quad$ Dunkley, op.cit. (note 22).

71 There is a burgeoning literature on the doctrine of linkages. This article does not explore that literature; see Alvarez et al., loc.cit. (note 1) (discussing the doctrine of linkage issue).

72 See Agreements between Specialized Agencies and the United Nations - ILO: Agreement came into force: 14 December 1946, available at: www.unsystemceb.org/reference/system/agreements (last accessed 27 January 2008). See also GA Res. 50(I), 14 December 1946, available at: www. unsystemceb.org/reference/system/agreements/ilo_unesco_fao_icao_a_50_1946 (last accessed 27 January 2008).

73 Dommen, Caroline, 'Raising Human Rights Concerns in the WTO: Actors, Processes and Possible Strategies', Human Rights Quarterly, Vol. 24, No. 1, 2002, pp. 1-50, at p. 1. 
the target date of $2015 .^{74}$ This is evidenced by Sub-Saharan African member States parties' increased resort to bilateral and regional trade agreements ${ }^{75}$ as alternatives to the multilateral system.

Whereas WTO looks to the creation of vibrant markets - in essence the stimulation and sustenance of a vibrant world economy that provides for efficiency and improved consumer-welfare everywhere, the UN looks to the improved political, economic, social, individual and group security of individuals everywhere. While these objectives may not be entirely mutually exclusive, the extreme emphasis by the WTO on the former compels a readjustment of priorities especially for the UN which caters for more than one issue. While the WTO appears to be a single issue organization, the UN deals with a diverse range of issues. They include environmental protection, economic security, political security, armed security, individual security, national security, minorities' security, and so on.

Consequently, by creating social tension through economic servitude and alienation WTO's extreme economic benefit radicalism usurps the UN's mission of ensuring international peace and security through respect of human rights of individuals, because the WTO modus operandi appears to undermine the economic welfare of the majority for the benefit of the few individuals in a few countries. By focusing only on demonstrable maximisation of gross international wealth, the WTO architects might have ignored the all-important question of whether economic growth should be achieved at any cost, including human rights and human development. This question has in the last half century exercised the debate about whether there is a need to strike a balance between the pursuit of economic growth and the pursuit of human development, and if so what that balance might be?

Obsession with economic growth has shown over the years that, while economic expansion is critical to human development, it must remain a means that does not ever take over as the policy driver. This obsession has shown also that economic development that is not adequately tempered with concerns about human welfare can be 'ruthless, by benefiting some at the expense of others; voiceless, by excluding the voice of people; jobless, by creating wealth but not jobs; futureless, by exhausting the next generation's resources; and rootless, by destroying cultural traditions and identities. ${ }^{76}$

Consequently, the voices that seek to counter what appears to be an obsession to equate global development with growth in gross domestic product (GDP) and gross

$74 \quad$ International peace and security is the UN's foremost concern. Several factors contribute to the achievement of this objective. The MDGs are a subset of this overall objective.

75 Discussing the practice of West African States, see Kufuor, Kofi Oteng, The Institutional Transformation of the Economic of West African States, Ashgate Publishing, Aldershot, 2006. Discussing Africa's economic and human development opportunities in the $21^{\text {st }}$ century, see also Konadu-Agyemang, Kwadwo and Panford, Kwamina (eds), Africa's development in the Twenty-first Century: Pertinent Socio-economic and Development Issues, Ashgate, Aldershot, 2006.

$76 \quad$ Fukuda-Parr, loc.cit. (note 36), at p. 396. 
international wealth are growing in number and not diminishing. ${ }^{77}$ They include the ILO that has long stood for the importance of differentiating in industry between human resources and capital resources, arguing for the recognition, protection and promotion of the dignity inherent in workers everywhere as human beings.

Research shows that in the 1980s basic human need theorists argued for development that focused on human needs. ${ }^{78}$ In the 1990s, self-actualisation economic theorists such as Amartya Sen and Mahbub ul Haq argued for human development that was driven by the need to create social and economic environments in which people everywhere could lead full and creative lives. ${ }^{79}$ The MDGs appear to be an embodiment and declaration of the supremacy in UN thinking of the primacy of human development over any other form of development.

However, WTO is radically international wealth maximisation centric. Its approach appears to be diametrically opposed to the MDGs. The World Bank's Independent Evaluation Group (IEG) 2006 Report on the impact of global trade programs between 1987 and $2004^{80}$ concludes that, while the strategy may have succeeded in opening up target countries' markets, it has not been as effective in boosting exports and growth and alleviating poverty. The Report examines the efficacy of the Bank's strategy of applying USD 38 billion (8.1 percent of the Bank's total commitments) to assist 117 developing countries become better integrated into the international economy. ${ }^{81}$

The United Nations Development Programme (UNDP) indicators for SubSaharan Africa chime the loudest about the WTO's apparent legitimacy deficit ${ }^{82}$ because of the apparent rift between its manifesto promise and the experience of different regions, States and categories of States. In its 2003 Report $^{83}$ UNDP warns

77 See especially ILO, A Fair Globalization: Creating Opportunities for All, Report of the World Commission on the Social Dimension of Globalization, ILO, Geneva, 2004; and Rajagopal, Balakrishnan, International Law from Below: Development, Social Movements and Third World Resistance, Cambridge University Press, Cambridge, 2003. Idem.

79 Idem.

80 World Bank Independent Evaluation Group, 'Assessing World Nak Support for Trade 1987-2004: An IEG Evaluation', The International Bank for Reconstruction and Development / The World Bank 2006), available at: www.worldbank.org/ieg/trade/docs/trade_evaluation.pdf (last accessed 27 January 2008). Ibidem, at p. xiii.

82 This is compounded by WTO's increasing failure to discharge its obligations under the Final Act Embodying the Results of the Uruguay Round of Multilateral Trade Negotiations Article 3(2), 15 April 1994, 33 International Legal Materials 1125, 1994, which provides that 'the WTO shall provide the forum for negotiations among its Members concerning their multilateral trade relations in matters dealt with under the agreements...' and it 'may also provide a forum for further negotiations among its Members concerning their multilateral trade relations.' Discussing the increasing disagreement in the Ministerial Conference of the WTO about the real issues that must be tackled, see Charnovitz, Steve, 'Triangulating the World Trade Organization', American Journal of International Law, Vol. 96, No. 1, 2002, pp. 28-55, at p. 28.

UNDP, Human Development Programme Report 2003 - Millennium Development Goals: A Compact Among Nations to end Human Poverty, Oxford University Press, Oxford, 2003, p. 16, available at: 
of a crisis in the decline in the Human Development Index ${ }^{84}$ (HDI) of 21 countries. This begs the question of whether the practice of the WTO system is: (i) consistent with its promise of making all member States parties better off; and (ii) compatible with the temporal economic and developmental aspirations of the United Nations Millennium Development Goals ${ }^{85}$ (UNMDGs) and of African States in particular as outlined in part in the Constitutive Act of the African Union (2002); ${ }^{86}$ the Banjul Charter; ${ }^{87}$ the Southern Africa Development Community (SADC) Treaty, ${ }^{88}$ the Economic Community of West Africa (ECOWAS) Treaty, ${ }^{89}$ the Community of SahelSaharan States (CEN-SAD) Treaty; the Common Market for Eastern and Southern Africa (CCOMESA) Treaty; ${ }^{90}$ and the Economic Community of Central African States (ECCAS). ${ }^{91}$

\footnotetext{
www.gateway.hr/files/d0000/gw_40gjp1.pdf (last accessed 27 January 2008).

84 The HDI is a summary measure of three dimensions of human development, namely, life expectancy, standard of education, and standard of living; see ibidem, at p. 34 .

85 See The UN Millennium Development Goals, available at: www.un.org/millenniumgoals/ (last accessed 27 January 2008). See also United Nations Millennium Declaration, supra note 37, at pp. 11-30.

86 See African Union, Constitutive Act of the African Union, 11 July 2000, available at: www.au2002. gov.za/docs/key_oau/au_act.htm (last accessed 27 January 2008).

87 See Organization of African Unity (OAU), African (Banjul) Charter on Human and People's Rights, adopted 27 June 1981, OAU Doc. CAB/LEG/67/3 rev. 5, 21 International Legal Materials 58, 1982 (entered into force 21 October 1986).

88 Southern African Development Community (SADC), Profile: Southern African Development Community, available at: www.africa-union.org/Recs/SADCProfile.pdf (last accessed 18 February 2008). See also Treaty of the Southern African Development Community, 17 August 1992, 13 International Legal Materials 120, 1993.
}

89 Economic Community of West African States - Revised Treaty, 28 May 1975, 35 International Legal Materials 663, 1996. See also About AU - Community of Sahel-Saharan States (CEN-SAD), available at: www.africa-union.org/About_AU/Abrecs.htm (last accessed 27 January 2008); and West Africa (ECOWAS) Energy Data, Statistics and Analysis - Oil, Gas, Electricity, Coal, available at: www.eia.doe.gov/cabs/ECOWAS/Background.html (last accessed 27 January 2008).

90 The Common Market for Eastern and Southern Africa (COMESA), 8 December 1994, 33 International Legal Materials 1072, 1994. See also About AU - Common Market for Eastern and Southern Africa (COMESA), available at: www.africa-union.org/About_AU/Abrecs.htm (last accessed 27 January 2008).

91 Economic Community of Central African States (ECCAS), 19 October 1983, 23 International Legal Materials 945, 1984. See also 'About AU - Economic Community of Central African States (ECCAS)', available at: www.africa-union.org/About_AU/Abrecs.htm (last accessed 27 January 2008). 


\subsection{SWEATING THE ASSETS UNDER THE MULTILATERAL WTO REGIME, BUT IN WHOSE FAVOUR AND TO WHAT EFFECT?}

The IMF claims that international trade and financial openness increased for both developed and developing countries in the early 1990s..$^{92}$ This was a time when IMF and World Bank economic structural adjustment programmes ${ }^{93}$ were being effected in some Sub-Saharan African countries. ${ }^{94}$ Trade and financial openness rose sharply from 1995 when the WTO agreement came into force and continues to strengthen, reflecting acceleration in globalisation.

Figure 3.7.1 below shows Trade and Financial Openness (Percent of GDP). Correspondingly, the African region has witnessed a net decline in economic performance, which increasing calls for more responsible trade liberalisation, which is meant to institutionalise alongside the WTO economic system, mechanisms 'for poverty and distributional outcomes, and to cushioning shocks associated with trade policies. ${ }^{95}$ The ILO based World Commission on the Social Dimension of Globalization Report (2004) observes that the marginalisation of some economies is due to deficiencies in the governance of trade liberalisation and not to trade liberalisation itself. But if there is nothing wrong with the medicine, why are some of its patients, the ones that need it the most, succumbing to its worst side effects?

Africa's marginalisation from the success of the international economic system is attributable in part to biased trade liberalisation where some States are able to give with one hand and take back with bucket loads. For instance, industrialised countries' subsidy regimes continue to undermine Africa's agrarian economies. The UN's Africa Renewal writes:

In 2001, cotton subsidies cost Mali, a West African nation highly dependent on the crop, $\$ 43$ million in potential revenue. This is more than Mali received in aid that year. (...) Donor countries responded to NEPAD by pledging, at the 2002 International Conference on Financing for Development, in Mexico, to increase the quality and quantity of aid to

92 International Monetary Fund, 'Trade and Financial Openness', available at: www.imf.org/external/ pubs/ft/weo/2006/01/chp3pdf/fig3_4.pdf (last accessed 27 January 2008).

93 Structural Adjustment Programmes involve conditional loans given to States by lending institutions. The 'conditions' often include privatisation of State enterprises and lifting import and export barriers that normally protect domestic labour markets from dumping cheap imports and subsidies. See Collier, Paul, 'The Marginalization of Africa', International Labour Review, Vol. 134, No. 4-5, 1995, pp. 541-557, at p. 541.

94 Notably Ghana, Somalia, Sudan, Tanzania, Zambia, Malawi and Zimbabwe, but other countries in this group did not have to make ESAPs, notably Botswana. See UNCTAD-UNDP Global Programme, 'Membership of UNCTAD and TDB', available at: www.unctad-undp.org/ (follow 'UNCTAD' hyperlink; then follow 'About UNCTAD' hyperlink; then follow 'UNCTAD's Membership' hyperlink) (last accessed 27 January 2008).

95 World Bank - Trade Evaluation Independent Evaluation Group, 'Assessing World Bank Support for Trade 1987-2004: An IEG Evaluation - Overview', available at: www.worldbank.org/ieg/trade/ (last accessed 27 January 2008). 
Africa. In 2002, the $\$ 22.2$ billion Africa received in aid was lower than the $\$ 26.6$ billion received in 1990. Most of the benefits of aid were lost through debt servicing, which amounted to $\$ 22$ billion in $2002 .{ }^{96}$

This experience is not limited to cotton, but extends to the raw-material base of SubSaharan African States. Little wonder that 'Fair Trade Stalls' and products are among the fastest growing business in Western Europe. ${ }^{97}$ This can be explained in part by the 'information generation' created by advances in technology in the last half century. Nonetheless, it also appears to point to the quest for social justice among informed citizens of the rich northern hemisphere, who are constantly organising and agitating for their governments to pursue fairer deals for children, farmers and workers of disadvantaged parts of the world that their governments have dealings with. ${ }^{98}$

The question of the link between trade liberalisation with so-called non-trade issues has only just begun to be examined. ${ }^{99}$ It raises social justice issues that comprise the core of the jurisdiction of ILO. ${ }^{100}$ Social justice is that which people generally conceive to encapsulate fairness and justice. Miller writes:

Social justice has always been, and must always be, a critical idea, one that challenges us to reform our institutions and practices in the name of greater fairness. ${ }^{101}$

The link between the enterprises of WTO and those of ILO is often acknowledged in terms that emphasise apprehensions about the effects on developing countries of trade liberalisation. ${ }^{102}$ Subsequently, perceived international economic inequality;

96 African Renewal, 'New African Report Urges Industrial Notions to Play Fair', www.un.org/ ecosocdev/geninfo/afrec/newrels/eca_era_04.htm (last accessed 27 January 2008).

97 See, for example, Fair Trade Superstore, available at: http://fairtradeuk.org/; The Fairtrade Foundation, London, UK, available at: www.fairtrade.org.uk/ (last accessed 27 January 2008). See also Office of Government Commerce (UK) Guidance on Fair and Ethical Trading, available at: www.ogc.gov.uk/documents/Guidance_on_Fair_and_Ethical_Trading.pdf (last accessed 27 January 2008).

98 The G8 now operates under immense international civil society pressure to alleviate poverty and suffering in Africa. See, for example, G8 Gleneagles 2005, 'Progress Report by the G8 Africa Personal Representatives on Implementation of the Africa Action Plan', available at: www.fco.gov. uk/Files/kfile/PostG8_Gleneagles_AfricaProgressReport,0.pdf (last accessed 27 January 2008).

99 Questioning the utility to analysis of issues of the idea of linkages. See also Leebron, David W., 'Linkages', American Journal of International Law, Vol. 96, No. 1, 2002, pp. 5-27, at p. 5.

100 See ILO Constitution, supra 66. See also Treaty of Versailles, Articles 387-427 (Part XIII), 28 June 1919, available also at University of San Diego website http://history.sandiego.edu/gen/text/ versaillestreaty/vercontents.html (last visited 27 January 2008).

101 Miller, David, Principles of Social Justice, Harvard University Press, Cambridge, 1999, p. x. See also Schmidtz, David, The Elements of Justice, Cambridge University Press, Cambridge, 2006, Chapter 1; Williams, Andrew, Social Justice, Blackwell Publishers, Oxford, Chapters 1-3; Rawls, John, A Theory of Justice, Oxford University Press, Oxford, rev. ed., 1999, pp. 52-78; and Dworkin, Ronald, Taking Rights Seriously, Duckworth, London, 1991, Chapter 6.

102 E.g., Torres, op.cit. (note 56). 
deterioration of labour protection across the world; and global economic instability are all attributed to trade liberalisation. This creates also the danger that perfectly legitimate concerns could be enthroned to the status of well-established facts. Instead of them being treated with caution, they then become pillars on which political pressures that are unfavourable to trade liberalisation, are mounted, regardless of their veracity. ${ }^{103}$

However, in an invaluable empirical study on jobs and incomes in a globalising world, Ghose ${ }^{104}$ found that the deficiencies of the policy of trade liberalisation are not self-evident and that such impressions can be wrong. For instance, the commonly held view among economists is that trade liberalisation has pitted unskilled workers of the regions of the world against one another. One result of this situation is that employers can easily relocate their businesses to the region offering them the most advantage. Often employers are influenced by among other things, the cost of labour and the legal protections afforded to labour.

The lower the cost of labour and the less tenuous the legal protection available to the labour force, the more attractive is the proposition of switching business to another region unless the labour lacks the required skills and the cost of shipping goods to the markets makes the relocation economically unwise. Therefore, unskilled workers in the industrialised world have to face declining real wages or risk unemployment, or both. Nonetheless, empirical research is yet to establish that such trends have been generated by the growth of trade with the developing world. ${ }^{105}$ Consequently, the link between trade liberalisation and marginalisation of African economies is at the very least problematic and deserving of scrutiny rather than summation in sound bites.

\subsection{THE MARGINALISATION OF SUB-SAHARA AFRICAN STATES UNDER THE WTO REGIME}

The prognosis on Sub-Saharan African economies in the last ten dozen years begs policy questions at various levels, all of which reflect its status. At the domestic level, the primary question is about governance. This is because governments that insist on collecting taxes, but refuse to account to the electorate, have never created strong, competitive and sustainable economies.

\footnotetext{
103 Ghose, loc.cit. (note 61), at p. 281. Discussing how misconceptions of GATT as an institution and WTO as a constitution fed the illusion that the latter had a legitimacy and authority it might otherwise not have, and is a mere treaty based on organisation. See also Cass, Deborah Z., The Constitutionalisation of the World Trade Organisation: Legitimacy, Democracy and Community in the International Trading System, Oxford University Press, Oxford, 2005, p. 63. Discussing the institutional character of the modern international trading system, See also Jackson, John H., The World Trading System, The MIT Press, Cambridge, 2002, p. 58.

104 Ghose, op.cit. (note 40).

105 Ghose, loc.cit. (note 61), at p. 282.
} 
At the regional level, the key issue refers to the physical, economic and social security of individuals on the continent. Economic oriented migration by Africans to other geographic regions of the world is a good indicator of the present welfare of citizens on the continent. A disproportionate number of African born and trained professionals, including medical physicists, dentists, nurses, engineers and teachers practice their vocations in Western Europe, while Africa manifestly evidences a lack of similarly skilled personnel.

At the international level, the key issue is whether Sub Saharan Africa could achieve the MDGs by the target date of 2015 under the WTO trade liberalisation wealth maximisation regime that bears no responsibility for the unequal distribution of the wealth and hardships that the system creates.

In spite of the fact that no region has yet made economic gains while disjointed from the world economy, research shows that the one international economic sphere in which Africa has remained unmarginalised is that of international aid. ${ }^{106}$ It shows also that Sub-Saharan Africa's share of trade and investment has declined to insignificance. ${ }^{107}$ Exceptionally, the volume of Africa's exports has grown less rapidly than gross domestic product (GDP). ${ }^{108}$ Sub-Saharan Africa has not participated in the substantial international growth in foreign direct and equity investment. ${ }^{109} \mathrm{~A}$ proportion of GDP private investment is lower in Africa than in other regions and is in decline. ${ }^{110}$

But should this prognosis be attributed to trade liberalisation? Ghose ${ }^{111}$ examined several factors that underpin this prognosis and concluded that there was not enough evidence to indict the current trade liberalisation project with marginalising developing countries' economies.

One factor is the all too often casually assumed link between international GDP which WTO seeks to grow in its campaign to maximise wealth creation on the one hand, and the status of Africa's GDP at the same time. Ghose found that the movement in the share of world exports in world GDP in the period 1960-1996 showed a steady, rising trend for the entire period. However, there was no noticeable deviation from that trend in the 1980s, when some States began to liberalise their economies, nor in the 1990s when that liberalisation was gaining momentum. In fact, in the same period, world GDP actually declined (see below, figure 3.7.1).

\footnotetext{
106 Collier, loc.cit. (note 93), at p. 541.

107 Idem.

108 Idem.

109 Lall, Sanjaya, 'Employment and Foreign Investment: Policy Options for Developing Countries', International Labour Review, Vol. 134, No. 4-5, 1995, pp. 541-557, at p. 541.

110 Collier, loc.cit. (note 93), at p. 541.

111 Ghose, loc.cit. (note 61), at p. 282.
} 
Figure 3.7.1. Corresponding decline in average annual growth rate of world GDP as States began to deepen economic liberalisation

\begin{tabular}{|c|c|c|}
\hline & Time Frame & Average Annual Growth Rate of World GDP \\
\hline 1 & $1960-1970$ & $5.3 \%$ \\
\hline 2 & $1970-1980$ & $3.5 \%$ \\
\hline 3 & $1980-1990$ & $3.1 \%$ \\
\hline 4 & $1990-1997$ & $2.3 \%$ \\
\hline
\end{tabular}

This evidence disproves any claims of leaps in world trade since the early 1980s when States began to deepen economic integration and some Sub-Saharan African States were beginning to implement economic structural adjustment programmes intended to stimulate their trade mainly through trade liberalisation. Therefore, based on this point alone, it could not be said that the current trade liberalisation project was culpable for the marginalisation of African States from the world economy.

Ghose $^{112}$ examined the share of exports in GDP for industrialised and developing countries in 1980 and then in 1995 . He found that in 1980 the share of industrialised States was 19.6 percent, dropping 0.3 percent in 1995 . This contrasts significantly with the experience of developing countries whose share rose from 23.4 percent in 1980 to 29.9 percent in 1995.

The possible explanations for this difference favour the view that the current trade liberalisation project is a double edged sword that industrialised States are more skilful at applying than developing States because first of all, the reliance by industrialised States on NTBs and subsidies leads to a protection of their domestic markets from competition of produce from developing countries' agrarian markets. Thus, while they have opened up their own markets to competition from industrialised States, developing States appear in the main to have obtained only an illusory corresponding comparable advantage. This reality has compelled them to increase their trade orientation while that of industrialised States has remained unaffected.

Secondly, the current trade liberalisation project began earlier for industrialised States and much later for developing States so that further liberalisation under the WTO did not require as much trade orientation for the former group of States as it did for the latter group. Research shows that the proportion of total merchandise exports for industrialised States with each other was static throughout the period between 1980-1996, suggesting 'the liberalising efforts of developing countries had little impact on the tendency of the industrialised countries to trade mainly among themselves.'113

In its short history so far, the current trade liberalisation project could be credited with having achieved a number of positive statistical economic outcomes only if the

$112 \quad$ Ibidem, at p. 285.

113 Idem. 
question is not asked about whether it is justifiable to allocate and minimise economic activity of States according to geographic, historic and aspirational location. The WTO's non-tariff barrier (NTB) and subsidy regimes are both capable of restricting economic activity of developing States to only what developed States are happy for them to do. In this sense, developing member States parties of the WTO are the children of the WTO family, and developed States the elders who bear authority over the rest.

This possibility has the potential to skew international trade by effectively wiping out any real advantage that the primary producers should obtain. Developing States appear to be most affected because of the monolithic inclinations of most of their economies. Nonetheless, such an outcome would have occurred anyway, even without the current trade liberalisation project because it is the WTO's failure to ensure genuine trade liberalisation in commodities that are the mainstay of the developing States' economies that has marginalised this group of States from any benefits of trade liberalisation. In this sense, the problem is not with the idea of trade liberalisation itself, but with disingenuous trade liberalisation.

The problem of unequal trade under the WTO paradigm stifles, instead of stimulating economic growth, and threatens countries whose primary exports are blocked by NTBs and subsidy regimes with growing problems of workless, no income, frustrated communities that need but cannot afford the manufactures of manufacturing economies. Whatever its virtues, such an economic system portrays graphically the international social injustice that may result and facilitate the commission of such international crimes as illegal economic migration, people trafficking, and many others in both the industrialised and the developing countries. More importantly it threatens realisation of the MDGs by 2015.

Section 4 of this article makes the case that the benefits of WTO inspired gross international wealth maximisation could be harmonised with UN aspirations including the goal of realising the MDGs by 2015 only if ILO ethics are allowed to affect the current WTO sponsored trade liberalisation project. This can be achieved by deliberate and purposive departures from extreme wealth maximisation to a reasonable wealth maximisation that is sensitive to domestic, local and universal concerns on the one hand, and continued support of such WTO adjustment by the $\mathrm{UN}$ on the other. 


\section{INEQUALITY AND THE QUESTION OF SOCIAL JUSTICE}

\subsection{SOME TENTATIVE OBSERVATIONS}

The ILO World Commission on the Social Dimension of Globalization's ${ }^{114}$ point of departure is a classical human rights argument that human beings everywhere share a common humanity regardless of their localised appreciation or understanding of that fact. ${ }^{115}$ That the common dignity of individuals ought to be recognised, promoted and ensured for individuals everywhere. This also is the purpose of the MDGs, which seek to mobilise support for human development in order to guarantee eight human rights standards for individuals everywhere. Therefore, there is an apparent connection between the goals of the UN as international vision caster of our times ${ }^{116}$ and ILO as social justice curator of the world. ${ }^{117}$ But the link ends there.

The international vision caster for the welfare and security of individuals everywhere and its social justice agitator alone cannot achieve their goals of human development with social justice without the support of the international trading system. Money has to be made to service both their goals.

The absence of this vital connection raises the question of the utility of an international trading system that is premised on the classic absolute, comparative advantage model if it disconnects its benefits from the welfare of the majority of citizens of the world. That question is encouraged by the failure of the system to facilitate the creation of decent jobs, provide for health insurance and basic education everywhere. ${ }^{118}$ International systems court legitimacy difficulties for themselves and risk disrepute when they are applied to harness global resources to the service of creating wealth from which the rest of the world is then alienated, and a handful of individuals in a few countries set to benefit - a subtle and legitimate slavery of the majority by the powerful minority.

114 This Commission was established by ILO to examine the phenomenon of globalisation, its dynamic, governance and impact on individuals everywhere and to recommend a strategy for social inclusion of everyone so that many and few could tap into the benefits of that phenomenon. In 2004, the Commission published its report under the title of 'A Fair Globalization, Creating Opportunities for all'; World Commission on the Social Dimension of Globalisation, loc.cit. (note 18).

115 Discussing the nature of human rights and the relativist/universalist dichotomy, see Donnelly, Jack, Universal Human Rights in Theory and Practice, Cornell University Press, Ithaca, $2^{\text {nd }}$ ed., 2003. See also Chigara, Ben, Amnesty in International Law: Legality under International Law of National Amnesty Laws, Longman, Harlow, 2002.

116 Although it is often castigated for being a cumbersome, unwieldy and often inefficient organisation in need of reform. See Alston, Philip, 'The Myopia of Handmaidens: International Lawyers and Globalization', European Journal of International Law, Vol. 8, No. 3, 1997, pp. 435-448. See also Reisman, Michael, 'Designing and Managing the Future of the State', European Journal of International Law, Vol. 8, No. 3, 1997, pp. 409-420.

117 The ILO and refugees, immigrant workers, HIV sufferers, and so on.

118 World Commission on the Social Dimension of Globalisation, loc.cit. (note 18). 
The international wealth that results from States' adherence to WTO international trade policies that: (i) minimise State protection of domestic social and political instability; and (ii) rely on strategies that perhaps unintentionally export domestic social economic difficulties and threaten global stability ${ }^{119}$ ends up in the hands of a few individuals in a few States. Even to the unreasonable person, this cannot be right. This itself is the epicentre of modern denial of human rights. Unless reform occurs in the international trading system, efforts to achieve the MDGs by the target date of 2015 will remain both hollow and disingenuous particularly for Sub-Saharan Africa.

On an elementary level, the reform could subject WTO policies to the UN's human security and development goals that seek to improve the welfare of individuals everywhere, especially through the development of the human rights project. This is because the international trading system depends upon people as workers that create international wealth, and again depends on people as markets for its produce. Remove people in either capacity or both and the international trading system becomes dysfunctional or obsolete. For this reason, the goals of the international trading system and its policies should be made to tally with those of the UN as global vision caster.

That does not appear to be the case at the moment. ${ }^{120}$ Global gini-coefficients point largely to a clear failure of the national economic systems of more than 80 percent of the world population to avert the social trauma and human insecurity that accompany economic insecurity. This picture is an inadvertent indictment of the modern international trading multilateral trading regime that champions the classic insights of absolute and comparative advantage economic theory developed by Adam Smith and David Ricardo, because affected States are member States parties of the multilateral WTO trading systems which is championing trade liberalisation. WTO's woes with legitimacy derive from the following:

- Findings of the UN bodies regarding human development vis-à-vis actual gross international economic wealth creation and real economic inequality within and between States. This is due largely to WTO's assumption that, if the rich are allowed to get even richer, economic benefits will move downward to the poor. Apparently this is not borne out by the facts. Therefore, this may be the most pretentious premise of the current WTO sponsored trade liberalisation project.

- Gini-coefficient test results, which point to a great potential social unrest because of the wide prevalence and extent of economic inequality within and between States. According to Vulliamy, even the US is in denial about economic inequality. 'For the first time in ten years the number of people caught in the poverty trap has suddenly increased. Unemployment is up from 4.2 per cent in 2000 to 5.7 per cent last year. While the middle class shrinks, the numbers living below the official

\footnotetext{
119 A fundamental assumption of the modern international trading regime. See Howse, loc.cit. (note 15), at p. 95.

120 See Martens, loc.cit. (note 29). See also UNDP, loc.cit. (note 29).
} 
poverty line of $\$ 18,104$ a year for a family of four has shot up to thirty-three million - from 11.3 to 11.7 per cent. That's the first increase since 1992. While President Bush's windfall tax breaks to the super-rich breezed through Congress (with Democratic help), the proposed rise in the minimum wage is frozen. ${ }^{\text {'21 }}$ Further, the proportion of children without health cover has increased from 63.8 percent to 67.1 percent. The poverty rate for children in the US is worse than in 19 'rich' countries, according to a study by the University of Michigan. ${ }^{122}$

- Its failure to attend to questions of unequal distribution of the gross international wealth that results from states' adherence to its trading regime raises the question of whether it is not culpably negligent of attending to questions of unequal distribution of the social power that it helps establish through the wealth it creates and leaves in the hands of a few people in a small number of countries. This has the potential of conflicting the WTO output with the UN focus as global vision caster for economic and human development. ${ }^{123}$ The MDGs are the UN's foremost concern at the moment. However, the unintended worst possible effects of trade liberalisation may kill any hope for their realisation, particularly in Sub-Saharan Africa where progress towards these goals is threatened also by decimation of populations through the AIDS pandemic, poor political governance and civil conflicts.

Therefore, there is a need, to refocus the WTO trading system so that its outputs simultaneously and deliberately facilitate UN goals and not undermine them. This calls first for an acknowledgment and rebuttal of the false premise that, if the rich are allowed to get even richer, economic benefits will trickle downward to the poor. This is the blind spot in the classic insights of absolute and comparative advantage economic theory. This can be achieved for instance by introducing a space for the ILO proven tools of social dialogue along the tripartite ${ }^{124}$ dimension to involve employer, employee and government representatives in the management of economic issues that affect people everywhere. ${ }^{125}$

As a policy, tripartism requires that all stakeholders within and between nation-States engage in social dialogue whenever matters referring to policy and

121 'US in Denial as Poverty Rises', Guardian Unlimited (UK), 3 November 2002, www.guardian.co.uk/ usa/story/0,825149,00.html (last accessed 27 January 2008).

122 Idem.

123 Since its inception the UN has championed development and protection of human rights standards, mobilised States' efforts to achieve economic and human development especially through the first, second and third UN development decades - 1960s, 1970s and 1980s respectively. Somavia regards the UN as the pillar of international co-operation for social development. See Somavia, Juan, People's Security: Globalizing Social Progress, International Labour Office, Geneva, 1999, p. 45.

124 See generally Trebilcock, Anne et al., Towards Social Dialogue: Tripartite Co-operation in National Economic and Social Policy-making, International Labour Office, Geneva, 1994, p. 3.

125 See generally Torres, op.cit. (note 56), at pp. 51-66. See also Somavia, op.cit. (note 123). 
standard setting fall for consideration. In other words, no policy change could be inaugurated or effected, or new standards developed and implemented without the participation at both national and international level of the governments,' employers' and workers' representatives. This would go a long way to address unequal distribution of social power based economic inequality within and between States. It would eventually ensure that strategies are developed within the international trading system that put distribution at the centre so that the wealth that results from States' adherence to the WTO trading system begins to accrue to many and not the current few. ${ }^{126}$ This is because a major criticism of the UNDP Annual Report (2005) is that unequal distribution of social power in the modern international trading system has left the distribution of the gross international wealth of the system in the hands of the few and not the many.

The WTO's focus on markets appears to be both rigid and limited, because it focuses on artificial entities that are driven in part by people themselves. People predate and determine the existence and longevity of markets and not vice versa. The slave market was created by people and extinguished by the same species. Thus, the issue that the WTO ought to resolve, is both immediate and fundamental because it is critical to its own continuance.

Human beings are real, ready and resilient. It is in their nature to fight back against the scourge of disease, disaster and domination of any sort. However, markets are artificial creations of the powerful in society. They come and go as do their instigators. Often they extinguish themselves through inefficiency and/or illegitimacy. The economies of over 50 countries have deteriorated from when they first took up membership of the WTO. This has hastened perceptions of a legitimacy deficit in the multilateral WTO trading system.

This perception is supported also by the growth in Regional Trade Agreements (RTAs) as an alternative to the WTO multilateral trading regime. RTAS are defined as bilateral, trilateral or multilateral trading arrangements between States. Their design can take several forms including Preferential Trade Agreements (PTAs), Free Trade Agreements (FTAs), Economic Communities (ECs) and Development Communities (DCs). However, their purpose is always the same, i.e. to create sectoral trading relations.

Ng'ong'ola ${ }^{127}$ writes that member States parties of the Southern African Development Community (SADC) that was established in 1992, are parties to at least two RTAs. This is deliberate and not accidental because in spite of the specific benefits

126 A major criticism of the UNDP Annual report (2005) is that unequal distribution of social power in the modern international trading system has left the distribution of the gross international wealth of the system in the hands of the few while the majority go without.

127 Ng'ong'ola, Clement, 'Regional Integration and Trade Liberalization in the Southern African Development Community', Journal of International Economic Law, Vol. 3, No. 3, 2000, pp. 485-506, at p. 485 . 
that individual RTAs ${ }^{128}$ may contribute to international trade, the sum of their practice tends to undermine the institutional and economic development of the multilateral trade system. Specifically, RTAs are an institutional threat to the WTO. ${ }^{129}$

Successive failures of WTO Ministerial negotiations have shown that RTAs undermine the integrity of the multilateral system by draining States' enthusiasm for, and confidence in multilateral trade negotiations. Secondly, they create conflicts between RTAs and the WTO. For instance, RTAs are historically discriminatory. In this sense, they are counter to the non-discriminatory ethos of the WTO regime that is ensured by the MFN and NT principles. Third, they deplete States' energy and resources between WTO and RTA processes. Picker ${ }^{130}$ writes that these institutional harms are interrelated and self-reinforcing. More than half of all RTAs have been negotiated within the lifetime of the WTO. The WTO writes that

[t] he vast majority of WTO members are party to one or more regional trade agreements. The surge in RTAs has continued unabated since the early 1990s. Some 250 RTAs have been notified to the GATT/WTO up to December 2002, of which 130 were notified after January 1995. Over 170 RTAs are currently in force; an additional 70 are estimated to be operational although not yet notified. By the end of 2005, if RTAs reportedly planned or already under negotiation are concluded, the total number of RTAs in force might well approach 300.131

The irresistible question to ask becomes: what motivates the same member States parties of the multilateral WTO trading system to resort also to RTAs? Globalisation; continuing colonial associations; the desire to enhance regional security, competitive advantages, support and cooperation; and furthering of economic and foreign policy goals are often cited reasons for this development. ${ }^{132}$

The overwhelming view ${ }^{133}$ is that recovery of the WTO's diminishing integrity lies in the organisation's willingness to extend its benefits to the majority of individuals everywhere and not the current tiny minority in the Western world - something that WTO clearly has not factored into its blueprint. It is also argued that its focus should be on people and on globalisation with solidarity that contributes to the elimination of poverty, ${ }^{134}$ rather than on its current obsession with markets. Disillusionment with WTO's failure to ensure this is one way of interpreting the growing resort

128 See Picker, Colin B., 'Regional Trade Agreements v. the WTO: A Proposal for Reform of Article XXIV to Counter This Institutional Threat', University of Pennsylvania Journal of International Economic Law, Vol. 26, No. 2, 2005, pp. 267-319, at pp. 273-275.

129 Ibidem, at p. 270.

$130 \quad$ Ibidem, at p. 271

131 WTO Regional Trade Agreements Gateway, available at: www.wto.org/english/tratop_e/region_e/ region_e.htm (last accessed 27 January 2008).

132 See Picker, loc.cit. (note 128), at pp. 273-279.

133 Too numerous to list, but see UNDP, loc.cit. (note 29), for the particular views.

134 Ibidem, at pp. 5-6. 
by States to regional and bilateral trade agreements in spite of the overwhelming endorsement of the multilateral trading system as shown by the high membership of the organisation.

\section{CONCLUDING REMARKS}

Aggregation of the social impact of trade liberalisation shows that it has been an instrument of social progress in that it has created wealth, expanded opportunities and provided a nurturing environment for entrepreneurship and enterprise ${ }^{135}$ for some individuals within specific countries, and also for some countries within specific regions and for some regions of the world but not for all. It shows also that it has so far been an instrument for the institutionalisation of global social crisis in that it has ensured unemployment, poverty, and marginalisation for the majority of the world's people, nation-States and regional groups. ${ }^{136}$ This outcome spells the greatest tragedy for the world's weakest economic region by any standard - Sub-Saharan Africa. It also spells a legitimacy crisis for the current WTO sponsored trade liberalisation project. More importantly, it threatens the credibility of the UN as the global vision caster in that it appears to diminish the possibility of achieving the UN MDGs in Sub-Saharan Africa by the target date of 2015 .

This article examined in particular the possible impact of the current WTO sponsored trade liberalisation project on Sub-Saharan Africa's potential to achieve the MDGs by the target date of 2015. The article showed that the current WTO sponsored trade liberalisation project is nurturing and strengthening economic inequalities between and within economic regions of the world and also between and within States themselves without making any attempt institutionally to mitigate them.

This scenario is unacceptable because ultimately, it is a threat to both the establishment and maintenance of international peace and security. The article recommends first, the adoption by WTO of institutional and policy interventions that target the offsetting in Sub-Saharan Africa of the unintended worst possible effects of the current WTO sponsored trade liberalisation project. In this connection, WTO needs to adopt and implement measures that ameliorate, reduce and prevent as much as is humanely possible, the occurrence and nurturing of social injustice in the pursuit of wealth maximisation. Secondly, WTO could also adopt and implement measures that seek to facilitate the redistribution of the wealth that results from states' adherence to its policies. WTO's current insatiable obsession with seeking to maximise gross international wealth is dislocated from concerns about the distribution of that wealth. The presumption that once created the wealth will necessarily trickle down to the needy poor is illusory, catastrophic and irresponsible.

\footnotetext{
135 See also Gunter and Van der Hoeven, loc.cit. (note 5), at p. 17.

136 Idem.
} 
Thirdly, this could be facilitated by ILO monitoring of the WTO enterprise, especially in Sub-Saharan Africa to ensure social justice for people of that region. This should include ILO training and offering of direct guidance and assistance to government departments and officials of Sub-Saharan African States on such matters as negotiation, reception and management of foreign direct and indirect investment schemes, and ensuring that foreign investors observe the minimum industrial relations policies enjoyed by workers in the developed world. In this sense, ILO would become the broker and insurer of equal dignity of labour for Sub-Saharan African workers. These changes should increase the chances of the UN to achieve its MDGs in Sub-Saharan Africa by the target date of 2015.

This article examined the prospect in general of securing the economic welfare of African people, which appears for the moment to lie on the continuum between WTO and ILO pursuits. It showed that the agendas of the WTO and the ILO present the most acute ideological contrast in modern international law. They each declare immutable principles that set off the battle for the soul of individual Africans' economic welfare. Failure by stakeholders to identify and deal with the challenges this raises is a sure catalyst for problems that others have conveniently classified as non-trade issues. The resolution of the appearance of tension between the enterprises of WTO on the one hand and ILO on the other may be the key to achieving the UN MDGs in Sub-Saharan Africa by the target date of 2015 . 